\title{
Heinrich Himmler og mindesmærkerne ved Danevirke
}

\author{
Af Johan Hvidtfeldt.
}

Den 28-ârige Heinrich Himmler fra Bayern blev 6. januar 1929 SS-rigsfører, hvilket betød, at kernen i de nazistiske stormtropper stod under hans kommando. SS's særlige efterretningstjeneste, Sicherheitsdienst (SD), bygget op af Reinhard Heydrich fra $1931,{ }^{1}$ blev snart et frygteligt våben i nazismens og Himmlers hænder. Efter magtovertagelsen i 1933 og opgøret med SA-chefen i 1934 var rigsførerens stjerne $i$ hurtig stigen. Han blev politipræsident $i$ Bayern 1933, chef for rigets politiske politi 1935 og leder af alt politi året efter. 1943 blev han indenrigsminister. Under krigen lykkedes det ham på en máde at opbygge sin egen hær, våben-SS, og mordforsaget pâ Hitler 20. juli 1944 forte med sig, at han fik befalingen over den tyske "Ersatzheer «. En frygtelig magt var lagt $i$ denne mands hånd.

Himmler var mere end nogen anden af de ledende nazister besat af "germanertroen". Helst havde han set, at hele det tyske folk - eller i hvert fald SS - på en måde blev ligesom hensat til en ældre germansk tidsalder. Han elskede at bruge gamle germanske symboler, som f. eks. runer. Der kan næppe være tvivl om, at denne dyrkelse af germanerne og den germanske tid har nærmet sig det sygelige." Den gav sig dog en række praktiske udslag. Optaget, som han var, af fortiden har han således i 1935 ledet udgravninger i Østpreussen for at vise, at den germanske races ekspansion mod øst var ældre end de tyske ridderes erobringer." Et SS-institut, Das Ahnenerbe, skulle især foretage undersøgelser over den tyske arv fra forfædrene og gennemførte også arkæologiske undersøgelser." Rigsminister Rosenberg havde ligesom rigsføreren stor interesse for udforskningen af "forhistorien og den tidlige historie «, men han så efterhånden med den største 
skepsis pâ Himmlers institut. Han mente, der var tale om at » forvandle et forskningsfællesskab til et instrument for de mest personlige instinkter ${ }^{\mathrm{s}}{ }^{\mathrm{s}}$

Himmlers livlæge, finnen Felix Kersten, der havde et større personligt kendskab til Himmler end de fleste, har fortalt om dette mærkelige og uhyggelige menneske, om hans meninger og hans naive tro på den germanske fortid. Han fortæller, at Himmler søgte at udvide sin viden gennem den nyeste litteratur. * Man kunne slet ikke forestille sig ham, uden at han læste. For han sov ind, også selvom han var nok så træt, tog han en bog $i$ hånden «. En vasentlig ting ved Himmler var, at en bestemt forestilling om mennesket var afgørende for hele hans tankegang, og den byggede på historiske forbilleder. Det var det germanske menneske, om hvis tilværelse og handlinger, Himmler havde en bestemt opfattelse, taget fra studiet af historien, som han i retningslinier og ledetråde gjorde til uforanderlig norm, først for sin SS, og hvorefter han i fremtiden ville omforme hele det tyske folk «. Kersten siger, Himmler var af den opfattelse, at hvad forfædrene havde gjort, var uden undtagelse godt og rigtigt. Nâr han stod oven for vanskeligheder, han skulle overvinde, sogte han historiske eksempler i stedet for at løse dem ud fra nutidens krav. "Ethvert aktuelt sporgsmál forsøgte han løst i nationalsocialistisk ånd, og det var for Himmler de germanske forfædres and. Historien var for ham en eneste kilde for, hvorledes man må handle i nutiden. Lykkedes det at finde eksempler fra den germanske historie, så var retningslinierne for ojeblikkets handling givet, enhver afvigelse gjaldt $i$ virkeligheden som en forsyndelse mod forfædrenes ånd "."

Rigsfører-SS var en mægtig mand. Hans beundring for den germanske fortid har vel nok forekommet mange naiv. Men den var velkendt, og i det følgende skal fortælles, hvorledes Himmler medvirkede til i 1939 og 1942 at redde nogle af de værdifuldeste mindesmærker i nærheden af Danevirke, først og fremmest de tre mægtige gravhøje og det, der var tilbage af Kovirket.

Ved krigsudbruddet begyndte det tyske luftvåben på en omfattende byggevirksomhed i Slesvig-Holsten. Der skulle bygges 20 nye flyvepladser. Den 8. december 1939 skrev Rigsfører-SS, Hein- 
rich Himmler til statssekretær, flyvergeneral Erhard Milch, der også var generalinspektør for luftvåbnet. Han fortalte, at han havde fået en omfattende beretning fra $\gg$ Forschungs- und Lehrgemeinschaft Das Ahnenerbe‘, og på grundlag deraf ville han nu henlede Milchs opmærksomhed på, at luftvåbnets byggevirksomhed i Slesvig-Holsten samt $i$ Oldenburg- og Hannoverområderne ville gå stærkt ud over mindesmærkerne fra forhistorisk og tidlig historisk tid. Alene indenfor det kielske forhistoriske museums arbejdsområde ville i løbet af de fire næste måneder 200 , delvis store, gravhøje blive sløjfet. I forbindelse med en forestående udvidelse af flyvepladsen Jagel syd for Slesvig ville en del af Hærvejen, den eneste godt bevarede del af Kograven - den tyske betegnelse for Kovirket - $400 \mathrm{~m}$ af Danevirke og tre mægtige gravhøje blive tilintetgjort. Ved den hidtidige planlæggelse var de blevet holdt udenfor ødelæggelserne. Himmler skriver, at >derved vil et enestående mindesmærke fra vor fortid $i$ landet forsvinde for evigt «. Det vil være særlig smerteligt, fordi disse mindesmærker nøje hører sammen med Hedeby.

Rigsføreren ville være general Milch taknemlig, hvis han i forståelse med den stedlige byggeledelse ville foranledige, at der i alle tilfælde ville blive vist den bedste forståelse for den betydning, det havde at beskytte mindesmærkerne, og at man $i$ byggeplanen ikke inddrager arealer, som man kan undgå at benytte.

Tre uger senere, den 29 . december 1939, svarede general Milch, at den skete udvikling med hensyn til de historiske mindesmærker også havde givet ham store bekymringer. Det var nu lykkedes at finde frem til et kompromis, således at der både blev taget hensyn til den af krigen betingede nødvendighed, og man samtidig opnåede at skåne fortidens minder. Det var sket under medvirken af museet $i$ Kiel og en særlig afdeling under overpræsidenten, der havde med beskyttelse af mindesmærker og hjemstavn at gøre. Herved kunne ihvertfald en del af mindesmærkerne skånes. I de tilfælde, hvor det ikke var muligt, skulle fagfolk have lejlighed til at gennemføre "sachgemãssen Aufnahmen * før tilintetgørelsen, og der skulle stilles penge og arbejdskraft til rådighed for udgravningen. De områder, som Himmler særlig havde nævnt, ville luftvåbnet nu ikke gøre krav på. > Af de samme grunde, som blev fremsat i Deres ovennævnte skrivelse, har man, 
for at kunne bevare Kovirket, ændret planlæggelsen af startbanen således, at det historisk værdifulde område skånes «. En del af Oksevejen må dog inddrages under de nye anlæg. Milch fortæller endvidere Himmler, at han endnu engang har givet kommandoen for det pågældende luftområde - Luftgau - anvisning på, i den udstrækning det nu engang er muligt, at skåne mindesmærkerne fra forhistorisk og tidlig historisk tid ved eventuelle yderligere forholdsregler i det nævnte område. Han mener iøvrigt ikke, der er grund til at frygte yderligere beslaglæggelser, da det nuværende program i det væsentlige kan anses for afsluttet.

Den 15. februar 1940 kunne den kendte arkæolog Jankuhn, der har indlagt sig megen fortjeneste ved udforskningen af Hedeby, meddele, at den bygningsmyndighed indenfor luftvåbnet, som havde ansvaret for udbygningen af "Flyvepladsen Slesvig-Land , i begyndelsen af januar 1940 havde oplyst, at man ikke behøvede de pågældende områder og var villig til at omgive de arealer, der var fredet, med et gærde. Han fastslår i brevet, at det er ved rigsførerens indgriben, at , det vigtigste stykke af Kovirket, en smuk del af den middelalderlige Hærvej og rækken af imponerende gravmindesmærker ved Hærvejen fra sten- og broncealderen er blevet bevaret fra ødelæggelsec. Jankuhn nævner også, at det var ved Heinrich Himmlers indgriben $i$ foråret 1939, at det lykkedes at redde Tinghøjen på Sild. Desværre har det nu vist sig, at det blev nødvendigt at afgrave den, idet den lå dér, hvor flyveplads Vesterlands startbaner skulle være.

I de følgende år var der ro om Danevirke-mindesmærkerne, men i oktober 1942 kom regeringsinspektør Rödiger fra, Fliegerhorst, Kommandantur L, Schleswig-Land * til museets direktør, dr. Schwantes, og meddelte, at da der skulle bygges en ny startbane, måtte ca. $300 \mathrm{~m}$ af Kovirket afgraves, ligesom gravhøjparret "Twebargen * og en gravhøj i nærheden af Kovirket måtte forsvinde. Den 24. oktober rettede Schvantes derefter en henvendelse til ,Luftgaukommando XI* i Hamborg. Han gør rede for mindesmærkerne og deres betydning i historien og siger, at hvis projektet bliver til virkelighed, ville det betyde tilintetgørelse af set af de mest vidunderlige landskaber i dette område, der er så rigt på fortryllende steder og ligger $\mathrm{i}$ nærheden af Hedeby og Danevirke . Ved alle de utallige omvisninger, ssom vi foretager 
betydeligt stærkere end i skrivelsen til "Luftgaukommando XI . Hedeby og de mindesmærker, der hører dertil, er sikke blot et hjerteanliggende for Slesvig-Holsten og Danmark, men for hele Tyskland og hele den interesserede verden ". Her er tale om et brændpunkt for den internationale videnskabelige interesse, og selv i den hårdeste krigstid må man ikke lade det åndelige livs imponderabilia ude af betragtning. Tit viser de sig at være af større vigtighed end de kendsgerninger, der skabes af krigsguden «. Uanset de krav, som krigens nødvendighed stiller, så er han bange for, »at engang vil gennemførelsen af en sådan plan trods alt på en eller anden måde blive fremstillet som en barbariets handling «. Hertil kommer endelig, at da museumsfolkene og andre sagkyndige er indkaldt til militærtjeneste, vil man ikke have mulighed for at foretage selv en yderst nødtørftig udgravning. Til slut nævner han, at da man tidligere måtte fjerne en lille, iøjnefaldende del af Kovirket, blev der afgivet en udtrykkelig forsikring om, at den eftergivenhed, der var vist $i$ denne sag, ville beskytte mod alle videre angreb på Kovirket og de mindesmærker, der ligger i nærheden deraf. Han beder rustningsinspektionen om, at dette højtideligt afgivne løfte nu også bliver holdt.

Nogle få dage senere, den 28 . oktober 1942, greb dr. Schow, der var Landeshauptmann der Provinz Schleswig-Holstein«, ind i sagen, idet han rettede en direkte henvendelse til Heinrich Himmler. Schwantes havde meddelt ham, hvad der forestod, og han giver en kort redegørelse for, hvad Kovirket er, og siger, at det er en del af det samlede Hedebyanlæg, , hvis beskyttelse De, rigsfører, har overtaget «. Han anmoder Himmler om på eftertrykkelig måde at støtte de forestillinger, som han selv har gjort hos rigsluftministeren, om at se bort fra udførelsen af det nævnte projekt og søge en anden løsning af pladsspørgsmålet.

Også "Das Ahnenerbe var blevet underrettet, og den 30. oktober blev der herfra rettet en henvendelse til dr. Rudolf Brandt, der var leder af »Abteilung Reichsführer-SS im Persönlichen Stab «. Man gør rede for sagen og henviser til Himmlers indgriben i 1939 og generalfeldmarskal Milchs erklæring ved den lejlighed om, at luftvåbnet ikke ville gøre krav på dette område. Det er absolut nødvendigt, at rigsføreren også denne gang henvender sig til 
Milch, og der vedlægges koncept til et sådant brev. Det hedder endvidere, at italienerne dog aldrig af militær nødvendighed antaster mindesmærker fra deres fortid. $\$$ Er de mindesmærker, vi har fra vor egen overlevering - og hvis tal er så meget ringere da mindre værd for os «. Til slut anmodes Brandt om at forelægge Himmler sagen ud fra dette synspunkt, for at der hurtigst muligt kan ske noget, før ulykken er fuldbyrdet. I udkastet til Himmlers brev redegøres for sagen og Milchs tidligere udtalelse, ligesom det også her understreges, at man i Italien aldrig ville handle på en sådan måde. >Vi har meget færre minder fra vor germanske fortid, og vi må derfor frede om dem og bevare dem for vort folk. Slesvig-Holsten er som ingen anden tysk provins, hvad dette angår, hellig jord «, og beskyttelsen af mindesmærkerne ved Hedeby ser for mig en hjertesag «.

Bortset fra en enkelt lille, betydningsløs rettelse godkendte Himmler konceptet, idet han egenhændigt signerede det *Ihr $\mathrm{H}$. Himmler*. Det blev afsendt den 11. november. Himmler var iøvrigt også fra anden side, landråden i Slesvig, SS-Standartenführer Kolbe, den 2. november blevet anmodet om at gribe ind overfor luftvåbnet. Samme dag henvendte Kolbe sig til flyvergeneral Wolf i Luftgau XI, Hamborg, med en indtrængende henstilling om i sidste time at hindre planens udførelse. Det ville være sen barbarisk handling, som i Slesvig-Holsten og den nordiske kulturkreds' historie ikke kunne gøres god igen, og som måtte vække forbavselse og harme $i$ hele den videnskabelige verden «. Selv for den jævneste bonde i Slesvig er Danevirke-anlægget en helligdom. Enhver folkefælle ville derfor med afsky fordømme disse planer og ville ikke på nogen måde kunne forstá luftvåbnets handlemåde. Ødelæggelserne ville ikke blot i Tyskland blive mødt med den største beklagelse, men ville også få vidtrækkende følger i udlandet. Oplysningerne herom ville via Danmark, som har > den største interesse i bevarelsen af Danevirke, nå frem til det fjendtlige udland, og vil efter min mening give et bidrag til den fjendtlige propaganda, som ikke må undervurderes «. Han beder derfor generalen om at give ordre til at trække planen tilbage og anmoder om, at flyvepladsens kommandant og byggeledelse får besked om at sætte sig i forbindelse med kredsens politimyndighed, landråden, før man tager fat på sådanne planer, og at spørge, 


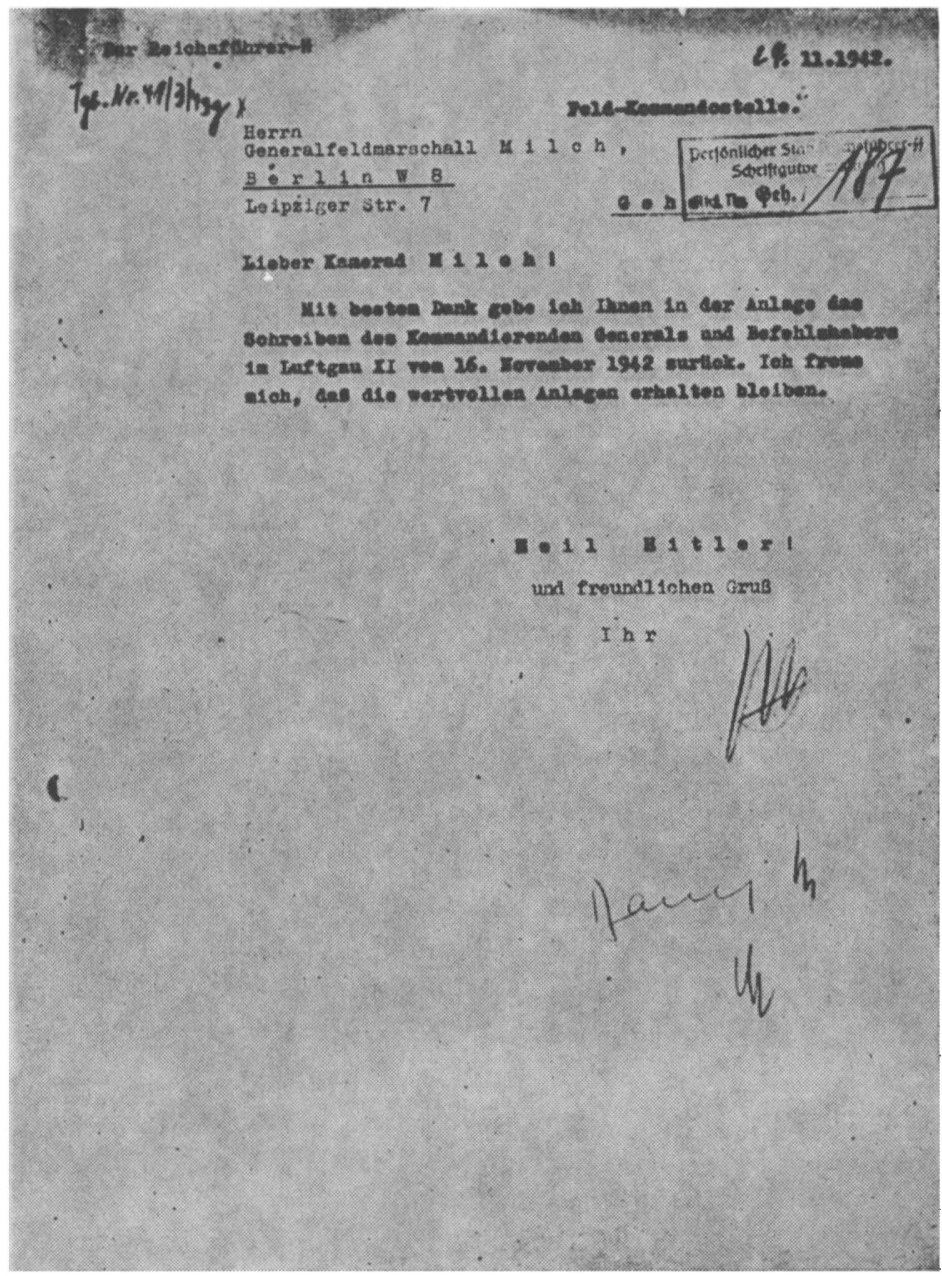

Gennemslag af Himmlers brev af 27. november 1942, det sidste $i$ denne sag. Rigsfererens egenhandige signatur findes under slutningsformularen.

om der er betænkeligheder derved. Landråden slutter med en oplysning om, at han har sendt den samme beretning til rigsforeren, som har særlig interesse for kulturhistoriske "Bauten.. Af Kolbes skrivelse til Himmler fremgår det iøvrigt, at også direktør Schwantes' to snødråb * blev sendt til rigsføreren.

Landrådens henvendelse til general Wolf førte hurtigt til et resultat. Allerede den 7. november 1942 kunne Kolbe meddele 
Heinrich Himmler, at dagen før var Wolfs generalintendant og kvartermester sammen med andre, der havde med sagen at gøre, blevet sendt til Slesvig for at drøfte den. Dette spørgsmål og alle andre problemer var blevet løst på tilfredsstillende måde. Han beder derfor om, at man vil afstå fra videre forholdsregler $i$ henhold til hans skrivelse af 2 . november. Kovirket var ikke mere $i$ fare. Dette brev må først være kommet Himmler i hænde, efter at hans skrivelse til Milch af 11 . november var afsendt. Generalfeldmarskallen havde iøvrigt svaret Himmler allerede den 12. I sit svar oplyste han. at han straks havde foranlediget det nødvendige « hos general Wolff og bemærker: »jeg slutter mig ganske til Deres opfattelse og Deres onsker og troede, at min indgriben i året 1939 ville have været tilstrækkelig for stedse*. Himmler takker Milch den 20., og fire dage senere returnerer han til generalfeldmarskallen en skrivelse af 16 . november - den findes ikke ved sagen -- fra general Wolf, hvori denne havde meddelt, at han havde opgivet planen efter intervention fra lokal side. Himmler slutter ledsagebrevet til Milch: > Jeg glæder mig over, at det værdifulde anlæg bliver bevaret $\alpha$."

Heinrich Himmler er vel ved siden af Adolf Hitler den mand, der bærer skyld og ansvar for de frygteligste, mest skæbnesvangre forbrydelser i menneskehedens historie. Menneskeliv spillede ingen rolle for ham, men fortidens historiske mindesmærker gjorde. Der kan ikke være tvivl om, at han har været med til at redde disse værdifulde levn fra vor fortid. Man kan vel aldrig få sig selv til at bruge udtrykket taknemmelighed $i$ forbindelse med Heinrich Himmler. Derimod vil der være grund til at mindes den indsats, som museumsfolk og administrationens mænd gjorde for at hindre denne sbarbariske handling .

\section{NOTER OG HENVISNINGER}

1. Gerald Reitlinger: The SS. Alibi of a Nation 1922-45, 1956, s. $31 \mathrm{ff}$.

2. Walter Hagen: Die geheime Front, 1950, s. 91.

3. Reitlinger anf. sted s. 15.

4. Smst. s. 90.

5. Serge Lang og Ernst von Schenk: Portrait eines Menschheitsverbrecher nach den hinterlassenen Memoiren des ehemaligen Reichsministers Alfred Rosenberg, 1947, s. 196.

6. Felix Kersten: Totenkopf und Treue, [1952], s. 390 f. Der findes to storre biografier af Himmler: Willi Frischauer: Himmler, the Evil 
Genius of the Third Reich, 1953, og R. Manvell og H. Fraenkel: Himmler, 1964.

7. Dette materiale såvel som det, der er benyttet $\mathbf{i}$ det følgende, findes i Persönlicher Stab Reichfürer-SS. Schriftgutverwaltung, nr. 187. Sicherstellung vorgeschichtlicher Denkmäler in Schleswig-Holstein 1939 42. Materialet har tidligere været i World War II Record Division i Alexandria lidt uden for Washington DC. Dette arkiv er en afdeling af det amerikanske rigsarkiv, National Archives. Så vidt vides er materialet nu afleveret til det vesttyske Bundesarchiv i Koblenz. Det havde i Record Division signaturen: EAP 161-b-12/25. En film herefter, taget af American Historical Association som et led $\mathrm{i}$ den store amerikanske fotografering af tysk arkivmateriale vedr. den nazistiske tid, findes i Rigsarkivet, og redegørelsen er udarbejdet på grundlag heraf; se Guides to German Records Microfilmed at Alexandria, Va. nr. 32, s. 18 f. Filmen har signaturen T. 175, spole nr. 20, optagelsernes nr. er 2525423-456. En ældre fotokopi af akterne findes i Library of Congress $\mathrm{i}$ Washington $\mathrm{D} \mathrm{C}$.

8. Også senere forsøgtes attentater på mindesmærkerne i Danevirkeområdet. Forfatteren Søren Telling havde den 18. oktober 1944 erfaret, at der skulle foretages fæstningsarbejder ved Slesvig. Der var tale om en parti-aktion, og det stod ham klart, at den ville berøre Danevirke-volden. Hos landråd Kolbe fik han oplysningen bekræftet, og efter at have indhentet tilladelse fra direktør Schwantes opnaede han dagen efter telefonisk forbindelse med SS-Standartenführer Siewers i Reichsführer SS Pers. Stab, Amt A, der havde med oldtidsmindesmærker at gøre. Samtalen varede i fem kvarter, og Himmler selv var nu og da også ’på ledningen «. Søren Telling fik ordre til at hindre ødelæggelsen af Danevirke $i$ en sådan grad, at arkæologisk forskning fremtidig umuliggjordes . Den 2. november forhandlede Telling ude ved Kurborg med planlægningsstaben, der bl. a. bestod af major Suhr og en hr. Bitterling fra 0 . T. Han videregav den modtagne ordre, men da der ikke forelå skriftlig bekræftelse, var staben yderst skeptisk, men udsatte dog aktionen til næste dag. Samme dag fik Søren Telling telegram fra Siewers, der bekræftede, at rigsforeren havde påbudt, at Bodendenkmäler auch unter gegenwärtigen Verhältnissen bei Befestigungsarbeiten weitmöglichst geschont und zu Tage tretende Funde geborgen werden. Stop. Beauftrage Sie hiermit alle notwendige Schritte zu unternehmen«. Med telegrammet i hảnden kunne Soren Telling den folgende dag mode sde arbejdslystne Partei-Herrer ude paa Slagmarken. Kampen var baade haard og naadesles. At sejre helt var umuligt. Ordet weitmöglichst tog Skærpen af Sværdet. Noget vandtes dog «. Jeg takker Søren Telling for disse oplysninger, som er givet i brev af 19 . oktober 1964 (med kopi af telegrammet), der delvis bygger på dagbøger fra den tid. 